\title{
Replacing Potassium by Phosphorus in Finnish CHD and Non-CHD Mortality Regressions by Fertilization Rates in 1961-2000 increased the Strength of Associations
}

Töysä T*

Licentiate of medicine, Specialty general practice, Rehabilitation hospital vetreaterveys Oy, Finland

Received: 此 August 10, 2018; Published: 嘀 September 05, 2018

*Corresponding author: Töysa T, Licentiate of Medicine, Specialty General Practice, Rehabilitation Hospital Vetrea and Terveys Oy, Pohjolankatu 15, FI-74100 Iisalmi, Finland

\begin{abstract}
Aim: Changes in human non-CHD (nCHD) mortality has not thoroughly been explained. Regressions by fertilization parameters, e.g. Mg/Ca and $\mathrm{K} / \mathrm{Mg}$, have been given and discussed. Daily allowance of phosphorus (P) is about double to the RDA. The possible role of excess phosphor fertilization on human general and vascular health has not got much attention. This study shows regressions of human CHD and nCHD(deathrates) in 1961-2000 by single and multiple fertilization parameters, assessing especially the difference caused by replacement of potassium with phosphorus in regressions by two parameters or parameter ratios. Mortality and fertilization (Eq/ha) data are from the same sources as earlier published. In the results parameters $\mathrm{x}$ are Nitrogen $(\mathrm{N})$, phosphorus $(\mathrm{P})$ and potassium $(\mathrm{K})$.

Results: Associations of $[\mathrm{P} / \mathrm{Mg}],[\mathrm{P} ; \mathrm{Mg}],[\mathrm{P} / \mathrm{NPK}]$ and $[\mathrm{P} ; \mathrm{NPK}]$ were stronger with $\mathrm{CHD}$ and $\mathrm{nCHD}$ than respective associations before replacement of $\mathrm{K}$ with $\mathrm{P} . \mathrm{x} / \mathrm{Mg}]$, explained stronger $\mathrm{nCHD}$ than $\mathrm{CHD}$, [x/NPK] explained them similarly and [x;NPK] explained stronger $\mathrm{CHD}$. [P;Mg] explained stronger $\mathrm{CHD},[\mathrm{N} ; \mathrm{Mg}]$ explained stronger $\mathrm{nCHD},[\mathrm{K} ; \mathrm{Mg}]$ explained them similarly. Regression coefficients were positive with $\mathrm{P}$ and $\mathrm{K}$, except single $\mathrm{K}$ with $\mathrm{nCHD}$. Regression coefficient was positive with $[\mathrm{N} / \mathrm{Mg}]$, but in other $\mathrm{N}$ regressions negative. Associations for given ( $\mathrm{N} 32$ ) regressions were highly significant $(\mathrm{p}<0.001)$ in all but three cases.
\end{abstract}

Conclusion: Many changes in fertilization are statistically associated with human mortality. Replacing K by $\mathrm{P}$ in CHD and nCHD regressions increased the strength of associations. Causes of associations are discussed.

Keywords: CHD; Non-CHD; Potassium; Phosphorus; Nitrogen; Magnesium; Fertilization; Time Related

Abbreviations: CHD: Age Adjusted Coronary Mortality (I20-I25) of 35-64yrs Old Humans (1/100,000); (here Calculated as Mean of Female and Male CHD), K: Potassium; Mg: Magnesium; N: Nitrogen; nCHD (mortality) - difference between Total and CHD Mortality; P: Phosphorus

\section{Introduction}

Associations of changes in fertilization with mortality have been represented earlier from different periods and different population groups [1-3] even including $P$ [1]. Low serum phosphorus concentration has been associated with lesser coronary calcification [4]. Excessive $P$ intake has been associated with carotid intima thickening [5] and to impair endothelial function [6]. In 1975-78 Finnish daily diet contained P $2000 \mathrm{mg} / \mathrm{d}$ [7], per 10 MJ [8]. Intake of phosphor was more than two-fold to RDA [9]. During the reduction of CHD mortality dietary intake of P seems to have been decreased, because 2012 it was ca 1880/10 MJ by middle aged people (men 1738 mg/9.4 MJ, women 1402 mg/7.3 MJ) [9].P-excess with low Ca and $\mathrm{Mg}$ in plasma are reported to be associated with spastic paresis and nervous excitation ("tetany" in cattle)[10], and so obviously with increased risk of fatal CVD with dynamic mechanisms [11]. On the other hand, harmful associations of P fertilizers with death-

rates could be explained by Mg precipitation in soil and cattle rumen as "very slightly soluble" MgNH4PO3 [12]. Suphur compound (gypsum) formed in superphosphate synthesis [12] is not included into the commercial superphosphate (error in [1]). The special aim of this mainly statistical study was to assess the difference caused by replacement of potassium with phosphorus in regressions by two parameters or parameter ratios.

\section{Materials and Methods}

Age adjusted total mortality of 35-64-y. females and males are from Valkonen and Niemi [13] and CHD death-rates from Valkonen and Martikainen 1990, for period 1951-68 [14]. Respective total and CHD mortality in 1969-2000 are from Statistics Finland [15]. Female (F) and male (M) total (TOT) and CHD mortality statistics $(1 / 100,000)$ are represented in [2]. Approximate for human CHD 
comes from equation: (FM.)CHD $=1 / 2 *(\mathrm{~F} . \mathrm{CHD}+\mathrm{M} . \mathrm{CHD})$. (FM.) ${ }_{\mathrm{n}} \mathrm{CHD}=$ $1 / 2^{*}$ (F.TOT+M.TOT) - (FM.)CHD. CHD and nCHD without prefix "FM" represent here "human" values. Approximated Mg rates per hectare are from [3]. Annual consumption of $\mathrm{N}_{2} \mathrm{P}_{2} \mathrm{O}$ and $\mathrm{K}_{2} \mathrm{O}$ fertilizers [16] and arable land [17] are from FAOSTAT. By them are calculated values for $\mathrm{N}, \mathrm{P}$ and $\mathrm{K} \mathrm{kg} / \mathrm{h}$. They are changed to equivalents (Eq/ ha) to help comparison. Values for K are totally represented in [3], $\mathrm{P}$ and $\mathrm{N}$ partially in [1].

\section{Results}

Table 1 In the group of single fertilizers Mg associated strongest with CHD and nCHD with negative coefficient. Next strongest

Table 1: Associations of mineral fertilizers or their combinations or ratios with CHD and non-CHD mortality.

\begin{tabular}{|c|c|c|c|c|}
\hline \multicolumn{5}{|c|}{$\begin{array}{c}\text { Associations of mineral fertilizers or their combinations } \\
\text { or ratios with CHD and non-CHD mortality }\end{array}$} \\
\hline & CHD & & FM.nCHD & \\
\hline & R square & coefficients & R square & coefficients \\
\hline $\mathrm{K}$ & 0.04 & $(+)$ & 0.028 & $(-)$ \\
\hline $\mathrm{P}$ & 0.409 & $(+)$ & 0.112 & $(+)$ \\
\hline $\mathrm{N}$ & 0.327 & $(-)$ & 0.635 & $(-)$ \\
\hline $\mathrm{Mg}$ & 0.537 & $(-)$ & 0.737 & $(-)$ \\
\hline $\mathrm{K} / \mathrm{Mg}$ & 0.675 & $(+)$ & 0.778 & $(+)$ \\
\hline $\mathrm{P} / \mathrm{Mg}$ & 0.693 & $(+)$ & 0.806 & $(+)$ \\
\hline $\mathrm{N} / \mathrm{Mg}$ & 0.439 & $(+)$ & 0.474 & $(+)$ \\
\hline [K;Mg] & 0.766 & $(+.-)$ & 0.756 & $(+.-)$ \\
\hline [P;Mg] & 0.844 & $(+.-)$ & 0.791 & $(+.-)$ \\
\hline [N;Mg] & 0.537 & $(-.-)$ & 0.789 & $(---)$ \\
\hline [K/NPK] & 0.732 & $(+)$ & 0.726 & $(+)$ \\
\hline [P/NPK] & 0.872 & $(+)$ & 0.873 & $(+)$ \\
\hline$[\mathrm{N} / \mathrm{NPK}$ & 0.86 & $(-)$ & 0.859 & $(-)$ \\
\hline [K;NPK] & 0.811 & $(+.-)$ & 0.734 & $(+.-)$ \\
\hline [P;NPK] & 0.953 & $(+.-)$ & 0.924 & $(+.-)$ \\
\hline [N;NPK] & 0.954 & $(-.+)$ & 0.906 & $(-.+)$ \\
\hline
\end{tabular}

Table 2: Summary of CHD and nCHD regressions, relative strength of associations, direction of coefficients. Mg coefficient was always negative. $(x=K, P$ or $N)$.

\begin{tabular}{|c|c|c|c|c|}
\hline \multicolumn{5}{|c|}{$\begin{array}{l}\text { Table 2. Summary of CHD and nCHD regressions, } \\
\text { relative strength of associations, direction of coefficients. } \\
\text { Mg coefficient was always negative. }(x=K, P \text { or } N)\end{array}$} \\
\hline CHD and nCHD & Strength of & & $\mathrm{x}$ & \\
\hline regression by & association with & $\mathrm{K}$ & $\mathrm{P}$ & $\mathrm{N}$ \\
\hline $\mathrm{x} / \mathrm{Mg}$ & CHD $<$ nCHD & $(+)$ & $(+)$ & $(+)$ \\
\hline $\mathrm{x} / \mathrm{NPK}$ & $\mathrm{CHD} \cong \mathrm{nCHD}$ & $(+)$ & $(+)$ & $(-)$ \\
\hline $\mathrm{x} ; \mathrm{NPK}$ & CHD >nCHD & $(+)$ & $(+)$ & $(-)$ \\
\hline $\mathrm{K} ; \mathrm{Mg}$ & $\mathrm{CHD} \cong \mathrm{nCHD}$ & $(+)$ & & \\
\hline $\mathrm{P} ; \mathrm{Mg}$ & CHD >nCHD & & $(+)$ & \\
\hline $\mathrm{N} ; \mathrm{Mg}$ & CHD $<$ nCHD & & & $(-)$ \\
\hline
\end{tabular}




\section{Discussion}

In the statistical replacement $\mathrm{K}$ by $\mathrm{P}$ increased the strength of associations with CHD and nCHD. Strong Mg deficiency is known to cause in man semicoma, tetany-like neuromuscular irritability in humans, which can be promptly cured by Mg administration [18]. Haaranen reported in 1968 that cattle hypomagnesemic tetany was associated with hyperphosphatemia [10]. On the other hand, parenteral administration of large amounts of $\mathrm{Mg}$ can cause anesthesia, which can be stopped in a few seconds by Ca [18]. Haaranen reported on somnolent paretic cows (flaccid paresis) on forest pasture with poor P content supplemented with excessive amounts of Mg (not on field pastures, with higher P content). They had high serum Mg and low Ca and especially low serum P [19] (Table 3). Possibly dietary P can regulate serum Mg and Ca levels. Grass (hypomagnesemic) tetany occurs most often in early spring and late autumn [20].

Table 3: Serum values of somnolent paretic cows with dietary $\mathrm{Mg}$ excess and P deficiency [19].

Table 3. Serum values of somnolent paretic cows with dietary Mg excess and $P$ deficiency [19]

\begin{tabular}{|c|c|c|c|}
\multicolumn{5}{|c|}{ excess and P deficiency [19] } \\
\hline & $\mathrm{Ca}$ & $\mathrm{Mg}$ & $\mathrm{P}$ \\
\hline $\mathrm{mmol} / \mathrm{L}$ & 1.40 & 1.98 & 0.13 \\
\hline$($ ref. mmol/L) & $2.17-2.74$ & $0.82-1.43$ & $1.45-2.58$ \\
\hline
\end{tabular}

This can be dependent on characteristics of biotite - the main Mg source of Finnish soils (rich in clay soils) [21]: The temperature dependent release of interlayer $\mathrm{K}$ is about one week faster than the release (by weathering) of $\mathrm{Mg}$ (and Si) [22]. High $\mathrm{K}$ installments on clay soils are reported not to decrease Mg herbage content as much as on the sandy soils [23]. Characteristics of biotite could partially explain the different variation of $\mathrm{Mg}$ (and $\mathrm{Si}$ ), $\mathrm{K}$ and $\mathrm{P}$ in early spring, dry and rainy summers [24]. Possibly depending on cold June $1974 \mathrm{Mg}$ contents of timothy were the same in clay and sandy soils in [25]. (Temperature in May 1974 was $2.7^{\circ} \mathrm{C}$ below the average $+7^{\circ} \mathrm{C}$ in randomly selected five Finnish towns - Helsinki, Turku, Kouvola, Jyväskylä and Kuopio) [26]. Maybe low Si content could not balance P values [27] in early spring and rainy summer [24]. Of course, the high $\mathrm{K}$ and $\mathrm{P}$ grass content in the spring can be based on high amount of fertilizers in early spring.

In 1978 was reported on high seasonal variation in grass $\mathrm{K}$ content and recommend giving $\mathrm{K}$ in multiple installments [28]. Between 1961-74 K/P ratio in fertilizers was quite constant why statistical differences are difficult to distract. So, there are several mechanisms, which could explain covariance of $\mathrm{K}$ with $\mathrm{P}$. They can partially explain why grass tetany index $\mathrm{K} /(\mathrm{Ca}+\mathrm{Mg})[20]$ can reflect availability of $\mathrm{P}$, too. Changes in $\mathrm{N}$-fertilization are associated with reduction of hay production (one yield/year) and increased silage production (tree yields/year). The inverse association of N-fertilizers in NPK-complex on mortality could possibly be explained by harms of excessive $\mathrm{P}$, benefits of silage, benefits of $\mathrm{N}$ on Mg uptake [29] and changes in selenium supplementation of fodder (+food) and fertilization [30]. These possibly exceeded the harms of antagonistic effect on Si content [31]. Amounts of N, P, and $\mathrm{K}$ are accurate, but Mg values are approximations [3].

\section{Conclusion}

Many changes in fertilization are statistically associated with human mortality. Replacing K by P in CHD and nCHD regressions increased the strength of associations. Causes of associations are discussed.

\section{Acknowledgement}

I am grateful to Professor OsmoHänninen and late veterinary surgeon Seppo Haaranen for several discussions.

\section{References}

1. Toysa Timo (2016) Compliance of Finnish Male CHD and Total Mortality with Soil Fertilization in 1957-1990. JJ Agriculture 2(1): 013.

2. Toysa T, Hänninen $\mathrm{H}$ (2017) Mg/Ca ratio in fertilization and agricultural soils, Mg percent of liming agents and human mortality in Finland during 1961-1990. J Afr Ass Physiol Sci 5(1): 29-40.

3. Toysa $\mathrm{T}$ (2018) Associations of $\mathrm{K} / \mathrm{Mg}$ fertilization ratio with non-CHD mortality in Finland during 1952-99. Biomed J Sci \&Tech Res 5(3).

4. Park KS, Chang JW, Kim TY, Kim HW, Lee EK, et al. (2011) Lower concentrations of serum phosphorus within the normal range could be associated with less calcification of the coronary artery in Koreans with normal renal function. Am J ClinNutr 94(6):1465-1470.

5. Itkonen ST, Karp HJ, Kemi VE, Kokkonen EM, Saarnio EM, et al. (2013) Associations among total and food additive phosphorus intake and carotid intima-media thickness--a cross-sectional study in a middleaged population in Southern Finland. Nutr J 12:94.

6. Nishi T, Shuto E, Ogawa M, Ohya M, Nakanishi M, et al. (2015) Excessive dietary phosphorus intake impairs endothelial function in young healthy men: a time- and dose-dependent study. J Med Invest 62(3-4): 167-72.

7. Varo P, Koivistoinen P Chapter XII (1980) General Discussion and Nutritional Evaluation. Mineral Element Composition of Finnish Foods: $\mathrm{N}, \mathrm{K}, \mathrm{Ca}, \mathrm{Mg}, \mathrm{P}, \mathrm{S}, \mathrm{Fe}, \mathrm{Cu}, \mathrm{Mn}, \mathrm{Zn}, \mathrm{Mo}, \mathrm{Co}, \mathrm{Ni}, \mathrm{Cr}, \mathrm{F}, \mathrm{Se}, \mathrm{Si}, \mathrm{Rb}, \mathrm{Al}, \mathrm{B}, \mathrm{Br}, \mathrm{Hg}$, $\mathrm{As}, \mathrm{Cd}, \mathrm{Pb}$ and Ash. Acta Agriculturae Scandinavica Supplementum 22. Stockholm 1980.

8. (2011) Koivistoinen (personal communication, 2011).

9. Helldán A, Raulio S, Kosola M, Tapanainen H, Ovaskainen ML, et al. (2012) Finravinto 2012 -tutkimus - The National FINDIET Survey.

10. Haaranen S (1968) Observations on hypomagnesemia with spasmodic symptoms on cows [in Finnish with English Summary], SuomenEläinlääkärilehti (Finnish Veterinary Journal): 212-223.

11. Bloom S (1986) Effects of magnesium deficiency on the pathogenesis of myocardial infarction. Magnesium 5(3-4): 154-164.

12. Pauling L (1964) College Chemistry. on p. 425. WH Freeman Company. San Francisco and London, UK.

13. Valkonen T, Niemi ML (1982) Age standardized mortality. The development of cardiovascular mortality in Finland from 1951-1978. Population Research Yearbook XX: 32-44.

14. Valkonen T, Martikainen P (1990) Development of mortality from ischaemic heart disease in subgroups of the population in Finland. [in Finnish with English Summary]. Sosiaalilääketieteellinen Aikakauslehti Journal of Social Medicine 27: 273-288.

15. Age adjusted coronary mortality (I20-I25) of men and women, 35-64 yrs, in Finland in 1969-2000. Source: (C) Statistics Finland, Causes of Death. 
16. Food and Agriculture Organization of the united nations.

17. http://www.fao.org/faostat/en/\#data/RL > DATA > Land.

18. White A, Handler P, Smith EL (1968) Priciples of Biochemistry. Chapter 48: 1015. McGraw-hill book company/kōgakusha company, LTD.

19. Haaranen S (1963) On magnesium question in cattle feeding. [in Finnish, with several tables.] ("Magnesiumkysymys nautakarjan ruokinnassa"). Karjatalous 1/1963 P. 3-5.

20. Kemp A (1957) Grass tetany in grazing milking cows. Netherlands J Agr Sci 5: 4-17.

21. Heinonen R (1956) On Magnesium Requirements on Finnish Agricultural Soils [in Finnish]. Agrogeological Publications 65. Helsinki.

22. Malmström M, Banwart S (1997) Biotite dissolution at $25^{\circ} \mathrm{C}$ : The $\mathrm{pH}$ dependence of dissolution rate and stoichiometry. Geochimica et Cosmochimica Acta 61(14): 2779-2799.

23. Potash Development Association (2017) Potash, Magnesium \& Sodium fertilizers for grass. (Accessed March 22, 2017).

24. Kuusela E (2006) Annual and seasonal changes in mineral contents ( $\mathrm{Ca}, \mathrm{Mg}, \mathrm{P}$ and $\mathrm{Na}$ ) of grazed clover-grass mixtures in organic farming. agricultural and food science 15(1): 23-34.

ISSN: 2574-1241

DOI: $10.26717 / B J S T R .2018 .08 .001696$

Töysä T. Biomed J Sci \& Tech Res

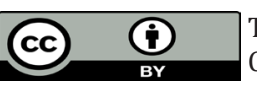

This work is licensed under Creative Commons Attribution 4.0 License

Submission Link: https://biomedres.us/submit-manuscript.php
25. Kähäri J, Nissinen H (1978) The Mineral element Contents of Timothy (Phleum pratense L.) in Finland. Acta agr Scand Suppl 20: 26-39. Table 8 on p. $34-35$.

26. (1961) Temperature and precipitation statistics from 1961 onwards

27. Ma JF, Takahashi E (2002) Soil, Fertilizer, and Plant Silicon Research in Japan, Chapter 8.3.4: 189.

28. Peltomaa R (1978) Potassium dressings in several installments for silage grasses. [in Finnish] ("Kalilannoitus useassa erässä tuorerehunurmille"). Koetoiminta ja käytäntö (Experimentation and Practice). Apr 25, 1978, on p. 17.

29. Jokinen R (1981) Requirements for Magnesium fertilization in Finland (dissertation December 18, 1981, Helsinki). J Sci Agric Soc Finland 53: 239-268.

30. Töysä T, Hanninen O, Haaranen S (2018) Human CHD and Pig Cardiac Mortality in Finland during 1954-1986. Biomed J Sci \& Tech Res 2(4).

31. Rinne SL, Sillanpää M, Hiivola SL, Huokuna E (1977) Effect of nitrogenous fertilization on silicon content of grass [in Finnish with a short Swedish summary Typpilannoituksen vaikutus ruohon piipitoisuuteen]. Kehittyvä Maatalous 35: 7-10.

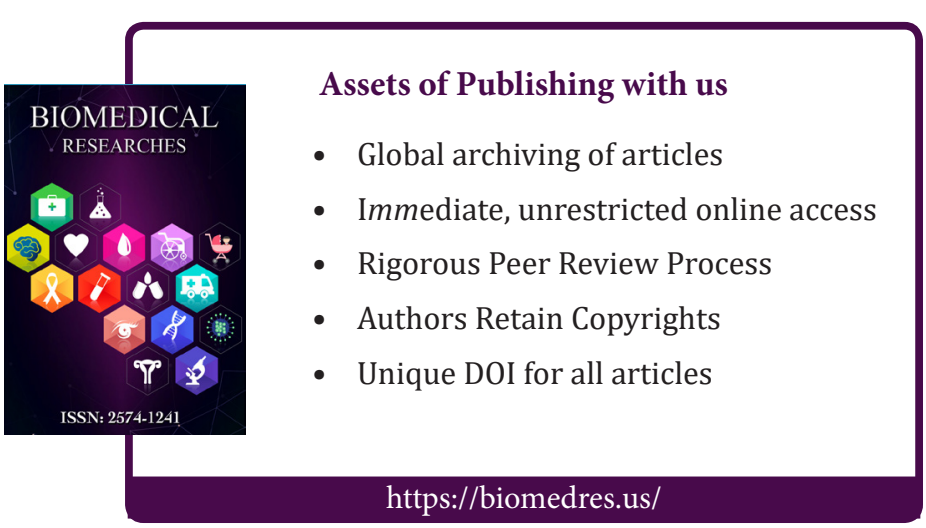

